\title{
Raising Awareness on the Turkish Learners of English about the Arbitrary Nature of Figurative Expressions
}

\author{
Assist. Prof. Dr. Abdulkadir ÇAKIR \\ Mevlana (Rumi) University, TURKEY \\ akcakir@mevlana. edu.tr
}

\begin{abstract}
In this paper, we have tried to remark the significance of the arbitrary nature of figurative expressions for the Turkish learners of English comparing English metaphors, similes, idioms, proverbs, sayings and collocations with their closest Turkish equivalents. If figurative expressions are interpreted literally or translated word for word, they sound nonsense. From the view point affective communication, inaccuracy or inappropriateness of the informative connotations of our words are irrelevant. Therefore, we may refer to the moon as "a beautiful lady", "a grandfather", "a tray", or "silver ship" or anything as long as the words arise the desired feeling. For that reason, literary works are difficult to translate from one language to another because regarding only the informative connotations will often falsify the affective connotations. Figurative expressions are based on some supplementary complements in the primary meaning and often they are arbitrary and conventional. Therefore, they are usually specific to a particular culture and language. For example, "an owl" is considered to be exceptionally clever in the Western culture but its most important connotation in the Turkish culture is its bringing bad luck. The traits assigned to animals and entities differ from culture to culture. Thus, to comprehend such figurative expressions and translate them properly is impossible without knowing their closest equivalents in the relevant languages. We can see the arbitrary nature of figurative expressions clearly examining some metaphors, similes, idioms, proverbs, sayings and collocations and their equivalents in the target language. We are of the opinion that this activity will enable us to raise awareness on the Turkish learners of English particularly on the prospective teachers of English and so that they will have the chance of becoming component speakers and writers.
\end{abstract}

Keywords: figurative expressions, connotations, equivalent

\section{Introduction}

An event or a quality can be described more comprehensively and strikingly through figurative expressions rather than using literal language as the traits of the animate can be used for the inanimate and vice-versa. That's why a car may "lie down and die",the wind "kisses" our cheeks, the waves are "angry" and "roar, the cliffs are "treacherous", the mountains "look down" on the sea, the machine guns "spit", revolvers "bark, volcanos "vomit fire" and engines "cough". That is to say that words have connotative meanings in addition to their conceptual meanings. In other words, they have affective connotations besides their informative values. For instance, "I have been waiting for ages" is a more effective way of saying than "I have been waiting for a long time. " Likewise, "He has got tons of money "is more effective than saying "He has got a lot of money". By the same token, "I am as hungry as a bear" is more effective than saying "I am very hungry."

If figurative expressions are interpreted literally or translated word for word, they sound nonsense. From the view point of affective communication, inaccuracy or inappropriateness of the informative connotations of our words are irrelevant. Therefore, we may refer to the moon as a beautiful lady", "a grandfather", " a tray" or " a silver ship" or anything as long as the words arise the desired feeling. For that reason, literary works are difficult to translate from one language to another because regarding only the informative connotations will often falsify the affective connotations. 
A word may have additional meanings assigned to it which are very different in every essential aspect from the primary meaning and where the link is not through essential components, such meanings are called" figurative". The more figurative the language is, the more extended the sense is. We must keep in mind that figurative expressions are those that extend the sense of a word in various directions. The comparison of "It is a fox. " with "He is a fox. " indicates that the former tells us the animal is a fox whereas the latter tells us about a man who is deceptively clever.

Figurative expressions are based on some supplementary complements in the primary meaning and often they are arbitrary and conventional. Therefore, they are usually specific to a particular culture and language. For example, "an owl" is considered to be exceptionally clever in the Western culture but its most important connotation in the Turkish culture is its bringing bad luck. The traits assigned to animals and entities differ from culture to culture. Thus, to comprehend such figurative expressions and to translate them properly is impossible without knowing their closest equivalents in the relevant languages.

We can see the arbitrary nature of figurative expressions examining some metaphors, similes, idioms and proverbs collocations and their equivalents in the target language.

\section{Metaphors and Similes}

Metaphors and similes are the main features of figurative language which often appear in the works of outstanding writers. They are the most effective ways of reflecting the writer's ability of seeing the striking resemblances and conflicting differences.

We can classify metaphors into three categories.

\section{Dead Metaphors}

Dead metaphors are the ones that have removed from their sources and whose figurative aspects are ignored. For instance, the hands of a watch, the branches of a river, a chain of stores, the eye of the needle and so on. Some dead metaphors are so commonly used for their quick and affective power that they have become a part of the ordinary language.

\section{Stock Metaphors}

The metaphors which reflect a speech community's culture are called "stock metaphors". They cover all kinds of social and cultural values of the society. They are difficult to comprehend. For instance, "horse" symbolizes "strength" in English but it is symbolized by "lion" in Turkish. Accordingly, "innocence" is symbolized by "lamb" in English but it is symbolized by "angel" or infant" in Turkish.

\section{Creative Metaphors}

It is also called original or live metaphor. This type of metaphor reflects particularly the writer's/ speaker's personal interest and imaginative power. Creative metaphor is the most common and convenient descriptive instrument in a language. It is often dramatic and shocking in affect as they establish points of similarity between one object and another without clearly stating what these resemblances are. For instance, the claws of darkness, the fingers of the fear, the heart of the problem, killing smile, the tears of love etc.

The images of some metaphors in different cultures overlap, thus, we have no problem in understanding them. We can mention most of the dead metaphors in this group. For example, a ray of hope, the circle of death, the leg of the table and so on. The images of some metaphors do not overlap but similar metaphors with different images can replace them. For instance, we use black days instead of rainy days in Turkish, "black eyes" replaces "blue eyes" in Turkish and instead of saying "sleep like a log" we say "sleep like a dead person or like a stone " in Turkish. If there is no equivalent of a metaphor in the target language, the sense behind the image should be interpreted analyzing the metaphor in detail. For example, "He keeps a good cellar. " refers to "He has a rich wine cellar", "My father" has green eyes" refers to "My father is a good gardener. "To make a mountain out of a mole hill" means "To turn a flea into a camel" in Turkish. We should bear in mind that a lexical word can have several metaphoric interpretations as seen in the above examples. 


\section{Similes}

Similes are not as difficult as metaphors as they are more precise and more restricted and they limit the resemblance of the object and its image to a single property. In a simile, the words "like" or "as.... as" are used to illustrate the nature of the comparison. The main problem may be cultural.

For instance, we say somebody is "as hungry as a wolf" instead of "as hungry as a bear".

\section{Idioms}

Idioms are special expressions composed of words with meanings assigned to the whole unit. In other words, the meaning of the whole idiom is not the sum of the meanings of the words that constitute it. Idioms reflect the way of living of the society that uses them and they change from language to language. Oxford Advanced Learner's Dictionary (2010:744) defines idioms as: "a group words whose meaning is different from the individual words. " For instance, "Let the cat out of the bag" is an idiom meaning to tell a secret by mistake. If we define idioms as phrases or word groups whose meanings cannot be predicted from the individual words that constitute them, then we have to stress that idioms are difficult to comprehend because of their arbitrary nature. For example, "apple polisher" literally means someone who polishes apples whereas its actual meaning is someone who flatters someone else. Another example is "upset the apple cart. "Its literal meaning is to cause the cart to fall on one side but its idiomatic meaning is to spoil someone's plan or arrangement.

Thinking the arbitrary nature of idioms, we can conclude that the best way to convey the meaning of an idiom is to find its equivalent in the target language.

The following are just a few examples to illustrate the arbitrariness of idioms.

\begin{tabular}{lll}
\hline \multicolumn{1}{c}{ Some Idioms } & Their Literal Meanings & Idiomatic Meanings \\
\hline 1. To paddle one's own canoe & To row one's own boat & To do your work on your own \\
2. To bite more than one can chew & $\begin{array}{l}\text { To try to eat something biting a too } \\
\text { big piece }\end{array}$ & $\begin{array}{l}\text { To attempt to do something } \\
\text { beyond your power }\end{array}$ \\
3. To pull the wool over one's eyes & To cover one's eyes with wool & To cheat somebody \\
4. To smell a rat & To smell a rat & To start to suspect \\
5. To pull one's leg & To drag one's leg & To play a joke on somebody \\
6. Straight from the horse's mouth & Directly out of a horse's mouth & First-hand information
\end{tabular}

It is not surprising that non-native speakers of English naturally have problems in understanding some idiomatic expressions and get confused since the true meaning of an idiom generally cannot be determined by studying its components.

\section{Proverbs and Sayings}

Obviously there are sayings and proverbs in every language which stem from the actual use of the language in course of years. Proverbs like idioms reflect the world view of the society and the way of living besides giving some clues about the culture and the history of that society. Proverbs express certain judgements made in different conditions by different people. Therefore, it is possible to meet conflicting proverbs in the same language for each proverb stems from certain experiences. Besides there are some proverbs borrowed from other languages as languages are living things. For example, "Don't put all your eggs into the same basket. ", is an English proverb but used in Turkish. 
Some proverbs especially culture-bound ones are difficult to comprehend unless you know their recognized equivalents in the target language. Let's examine some English proverbs and their equivalents in Turkish to have a clear idea about the problem.

\section{English Proverbs $\quad$ Turkish Equivalents}

1. Men make houses, women make homes.

2. One swallow does not a summer make.

3. Walls have ears.

4. Don't judge a book by its cover.

5. Birds of feather flock together.

6. If you can't stand the heat, get out of the kitchen.
1. The female bird makes the nest.

2. Spring does not come with one flower.

3. The floor has ears.

4. Don't be fooled by appearance.

5. Tell me about your friends, l'll tell you who you are.

6. Don't open a shop if you don't know how to smile.

\section{Collocations}

A collocation is a combination of words which frequently occur together. The meanings of some collocations can be predicted from the meanings of their components. Such collocations do not produce much difficulty for the learners. However, the meanings of many collocations cannot be predicted from their constituents as their meanings are arbitrary. Only the native speakers know their meanings somehow. There is arbitrariness in the use of constituents of many collocations. The words that seem to have the same lexical sense may have different semantic properties due to the company they keep. Language differs in the way they perceive the reality. Thus, to suppose that there exists a "word-forword" correspondence between any two languages is a misconception. However, that doesn't mean that the view of the world held by different linguistic communities is unbridgeable.

The following examples can illustrate how the same words may have different meanings when it occurs with different collocates.

\begin{tabular}{ll}
\hline Collocations & The meanings of them \\
\hline 1. Fresh water & Water without salt \\
2. Fresh horse & A vigorous horse \\
3. Freshman & First year student in a collage \\
4. Fresh air & Cool, clean air \\
5. Fresh vegetable & Newly collected(picked) vegetable \\
\hline
\end{tabular}

As we see in the above examples, the same word "fresh" has different meanings when used with different collocates.

\section{Conclusion}


As we know the culture of a society is reflected by the language spoken by that society. In other words, there is a close relationship between culture and language and language is the mirror of the culture. To understand the culture of the target community the figurative expressions, such as metaphors, similes, proverbs, sayings, idioms and collocations are of great significance and particularly prospective teachers of English should be aware of the arbitrary nature of figurative expressions to be component speakers and writers besides being good models for their students. Teachers of English can make their lessons more fun and more interesting making use of figurative expressions.

All in all, using figurative expressions is the most effective, interesting and attractive way of expressing one's ideas and emotions. There is no doubt that any writing, particularly, literary ones would be too boring, tasteless and colorless if figurative expressions weren't used.

\section{References}

Aksoy, Ömer Asım. (1976). Atasözleri ve Deyimler Sözlügü Cilt 1-2 Ankara: Türk Dil Kurumu Yayınları.

Çakır, Abdulkadir (2015). A comparative Study of Some Problematic Collocations for Turkish Learners. ERPA International Congresses on Education Athens- Greece, 04-07 June, 2015

Çakır, Abdulkadir (1996). How to Translate Metaphors and Similes. Selçuk Üniversitesi Eğitim Fakültesi Dergisi sayl:7 Konya.

Hatch, Evelyn and Cherly Brown. (1995). Vocabulary,Semantics and Language Education. Cambridge: CUP.

Hayakawa, S. I. (1949). Language in Thought and Action. NewYork: Harcourt,Brace and Company.

Hudson, Richard. (1995). Word Meaning London: Routledge.

Jackson, Howard. (1991). Words and Their Meanings London:Longman.

Lyons, John. (1995). Linguistic Semantics. Cambridge: CUP.

Larson, Mildred L. (1984). Meaning-based Translation. Boston: University Press of America.

Mc. Carty, Michael and O'Dell,Fellicity. (2005). English Collocations in Use. Cambridge:CUP.

Newmark, Peter. (1982). Approaches to Translation. NewYork : Pergamon Press.

Newmark, Peter (1988). A Textbook of Translation. United Kingdom: Prentice Hall.

Pala, İskeder. (2004). Ansiklopedik Divan Şiiri Sözlüğü, İstanbul, Kapı Yayınları.

Thornbury, Scot. (2002). How to teach Vocabulary Harbus: Longman.

Thornbury, Scot. (2004). Natural Grammar Oxford: OUP.

Yurtbaşı, Metin. (2012). Atasözleri Sözlüğü İstanbul : Barış Matbaası. 